\title{
Temporary Electrostatic Impairment of DNA Recognition: Light-Driven DNA Binding of Peptide Dimers
}

Adrián Jiménez-Balsa, Elena Pazos, Borja Martínez-Albardonedo, José L. Mascareñas, M. Eugenio Vázquez

\section{Peer reviewed version}

This is the peer reviewed version of the following article: Jiménez-Balsa, A., Pazos, E., MartínezAlbardonedo, B., Mascareñas, J. L. and Vázquez, M. E. (2012), Temporary Electrostatic Impairment of DNA Recognition: Light-Driven DNA Binding of Peptide Dimers. Angew. Chem. Int. Ed., 51: 88258829, which has been published in final form at https://doi.org/10.1002/anie.201201627. This article may be used for non-commercial purposes in accordance with Wiley Terms and Conditions for Use of Self-Archived Versions

\section{How to cite:}

Jiménez-Balsa, A., Pazos, E., Martínez-Albardonedo, B., Mascareñas, J. L. and Vázquez, M. E. (2012), Temporary Electrostatic Impairment of DNA Recognition: Light-Driven DNA Binding of Peptide Dimers. Angew. Chem. Int. Ed., 51: 8825-8829. doi:10.1002/anie.201201627

\section{Copyright information:}

(C) 2012 WILEY-VCH Verlag GmbH \& Co. KGaA, Weinheim. This article may be used for noncommercial purposes in accordance with Wiley Terms and Conditions for Use of Self-Archived Versions 


\title{
Temporary electrostatic impairing of DNA recognition. Light-driven DNA-binding of peptide dimers derived from a bZIP transcription factor
}

\author{
Adrián Jiménez-Balsa, Elena Pazos, Borja Martínez-Albardonedo, José L. Mascareñas* and \\ M. Eugenio Vázquez*
}

Gene expression relies on a myriad of carefully orchestrated interactions between specialized proteins called transcription factors (TFs) and regulatory DNA sequences. ${ }^{[1]}$ In general, such interactions are subtly regulated in time and space, so that many TFs remain inactive until receiving an appropriate activation signal. ${ }^{[2]}$ It is well established that the DNA readout by TFs largely relies on interactions between amino acid side chains and the DNA bases and phosphates. ${ }^{[3]}$ Among these contacts, those involving positively charged basic amino acids are critical for the thermodynamic stability of their DNA complexes. ${ }^{[4]}$ We reasoned that the temporary electrostatic deactivation of such contacts might provide for the development of TF-based systems whose DNA binding activity could be externally controllable, for instance by light. These systems could be useful tools for transcriptional control, ${ }^{[5]}$ or for probing spatiotemporal patterns of gene expression in living organisms. ${ }^{[6]}$ It is curious that despite the well established use of light-activated compounds in chemical biology, ${ }^{[7,8]}$ examples of photocontrolled DNA binding are certainly scarce. These include reversible switches based on the photostationary equilibrium of azo-modified DNA binders, ${ }^{[5,9]}$ special chromophores with poor DNA binding affinity and/or specificity, ${ }^{[10]}$ and single-use caging strategies for triggering minor groove binding or intercalation. ${ }^{[1]}$ Thus, inspired by the use of negatively-charged elements to modulate cell internalization, ${ }^{[12]}$ we sought to develop a general strategy for photocontrolling the sequence-specific DNA binding of TF peptide mimics

Herein we demonstrate that tethering polyanionic tails to basic DNA-binding bZIP peptides through a light-sensitive linker suppresses the DNA interaction. Upon irradiation, the negatively charged appendages are released, and the DNA-binding activity is thus restored. As reference system for implementing the strategy we

[*] Adrián Jiménez-Balsa, Dr. Elena Pazos, Borja MartínezAlbardonedo, Prof. José L. Mascareñas*, Prof. M. Eugenio Vázquez*

Departamento de Química Orgánica y Centro Singular de Investigación en Química Biológica y Materiales

Moleculares y Unidad Asociada al CSIC

Universidade de Santiago de Compostela

15782 Santiago de Compostela. Spain

Fax: (+34) 981595012

E-mail: eugenio.vazquez@usc.es

joseluis.mascarenas@usc.es

Homepage: http://www.usc.es/chembiousc/

[**] We thank the financial support provided by the Spanish grants SAF2010-20822-C02, CTQ2009-14431/BQU, Consolider Ingenio 2010 CSD2007-00006, and the Xunta de Galicia INCITE09 209 084PR, PGIDIT08CSA047209PR, and GRC2010/12. A. J. B. and E. P. thank the Spanish MEC and the Xunta for their PhD fellowships.

Supporting information for this article is available on the WWW under http://www.angewandte.org or from the author. chose the GCN4 transcription factor, an archetypical bZIP TF that specifically binds to ATF/CREB (5'-ATGA(c/g)TCAT-3') or AP1 (5'-ATGA(c)TCAT-3') sites as a leucine zipper-mediated dimer of uninterrupted $\alpha$ helices. The $\mathrm{N}$-terminal basic regions feature many positively charged amino acids that are key for the DNA recognition (10 Lys or Arg out of 31 residues in the basic region. Figure 1, GCN4br) ${ }^{[13]}$ It has been shown that the leucine zipper itself can be substituted by a number of dimerizing units without significant loss in the DNA binding properties. ${ }^{[14]}$ Therefore, in our first iteration for the design of the electrostatically impaired DNA-binding peptides, we selected the minimum sequence of the bZIP basic region (br) that it is known to retain the DNA binding ability when engineered as a disulfide dimer. ${ }^{[15]}$ This minimal peptide was extended at the Nterminus by adding acidic extensions with four or eight Glu residues, linked to the core br sequence through a photolabile 3-amino-3-(2nitrophenyl)-propionic acid (ANP) group. ${ }^{[16]}$ The disulfide control peptide $\mathbf{b r}_{2}$ was constructed by dimerization of the monomers containing a C-terminal cysteine, using Ellman's reagent in phosphate buffer. ${ }^{[17]}$ Peptide dimers $\phi(\mathbf{b r})_{2}, \phi\left(\mathbf{E}_{\mathbf{4}} \mathbf{b r}\right)_{2}$ and $\phi\left(\mathbf{E}_{8} \mathbf{b r}\right)_{2}$ were obtained in good yield by direct alkylation of each of the cystein monomers with 1,4-bis(bromomethyl)benzene.

GCN4br PESSDPAALKRARNTEAARRSRARKLORMKO br Aba-DPAALKRARNTEAARRSRARKLQ-GGC $\mathrm{E}_{4}$ br Aba-EEEE-O-DPAALKRARNTEAARRSRARKLQ-GGC $\mathbf{E}_{8}$ br Aba)-EEEEEEEE-o-DPAALKRARNTEAARRSRARKLQ-GGC

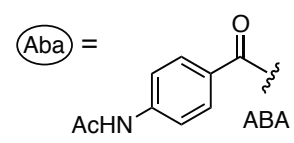<smiles>CC(C)CC1NCC(=O)N([O-])c2ccccc21</smiles>
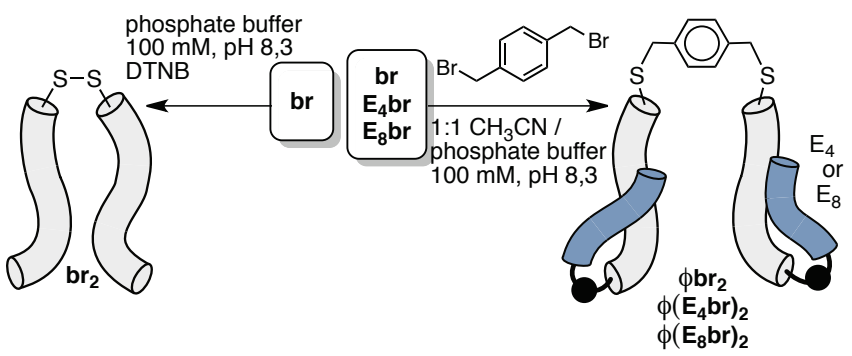

Figure 1. Top: Sequence of the GCN4 basic region highlighting the positively charged residues. Sequences of the acidic tail peptides, $\mathbf{E}_{4} \mathbf{b r}$ and $\mathbf{E}_{8} \mathbf{b r}$. Structure of the Aba chromophore (used as internal standard), and the ANP photocleavable linker (shown as •). Bottom: Dimerization reactions of $\mathbf{b r}, \mathbf{E}_{4} \mathbf{b r}$ and $\mathbf{E}_{8} \mathbf{b r}$ to give the corresponding control disulfide $b_{2}$, or benzylic dimers, $\phi b r_{2}, \phi\left(E_{4} b r\right)_{2}$, and $\phi\left(E_{8} b r\right)_{2}$. The acidic tails $\left(\mathrm{Glu}_{4}\right.$ or $\left.\mathrm{Glu}_{8}\right)$ are represented in the cartoons with darker grey, and the photocleavable element as a black circle. 
The DNA binding of $\phi \mathbf{b r}_{2}, \phi\left(\mathbf{E}_{4} \mathbf{b r}\right)_{2}$ and $\phi\left(\mathbf{E}_{\mathbf{8}} \mathbf{b r}\right)_{2}$ was studied by electrophoretic mobility shift assays (EMSA) under non-denaturing conditions, ${ }^{[18]}$ and using SYBR gold for DNA staining. Thus, a short ds-oligonucleotide containing the ATF/CREB binding site was incubated with each of the three peptides at $4{ }^{\circ} \mathrm{C}$. As a positive binding control we used the basic region disulfide dimer $\mathbf{b r}_{2}$, which in the presence of the ATF/CREB oligo gave the expected slower migrating band (Figure 2, lanes 2-4, band b). The $\phi \mathbf{b r}_{2}$ dimer displayed qualitatively similar binding properties as the positive control, albeit exhibiting a slightly reduced affinity (figure 2, lanes 5 and 6). Curiously, the dimer $\phi\left(\mathbf{E}_{4} \mathbf{b r}\right)_{2}$ also displayed measurable affinity for the target oligonucleotide, despite the presence of a significant number of negatives charges (two Glu $\mathrm{H}_{4}$ tails), as evidenced by the appearance of a retarded band in the gel similar that observed with the controls (figure 2, lanes 7 and 8). In contrast, the $\phi\left(\mathbf{E}_{\mathbf{8}} \mathbf{b r}\right)_{2}$, peptide, featuring the longer $\mathrm{Glu}_{8}$ acidic tails, was incapable of forming stable complexes in the electrophoretic gel, and only at high peptide concentrations it was possible to observe a faint, slower migrating band (lanes 9 and 10).

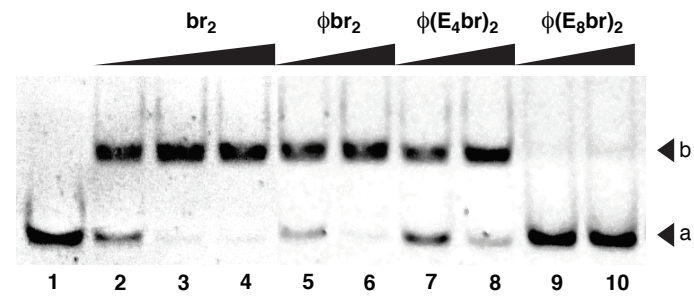

Figure 2. EMSA assays of DNA recognition. Lanes 1-10: target ATF/CREB dsDNA (50 nM). Lanes 2-4: 75, 150, 300 nM br ${ }_{2}$; lanes 5, 6: 150, $300 \mathrm{nM} \phi$ br $_{2}$; lanes 7, 8: 150, $300 \mathrm{nM} \phi\left(\mathbf{E}_{4} \mathbf{b r}\right)_{2}$; lanes 9, 10: $150,300 \mathrm{nM} \phi\left(\mathbf{E}_{8} \mathbf{b r}\right)_{2}$. Band a corresponds to the free ds-oligo; the slow-migrating band $\mathbf{b}$ corresponds to the DNA/peptide complexes. ${ }^{[19]}$ ATF/CREB (one strand shown, binding site in italics): 5'- TGGAG ATGA cg TCAT CTCGT -3'. Peptide and dsDNA in $5 \mathrm{mM}$ Tris- $\mathrm{HCl}$, $\mathrm{pH} 6.8,50 \mathrm{mM} \mathrm{NaCl},\left(4^{\circ} \mathrm{C}, 10 \mathrm{~min}\right)$ were added to $18 \mathrm{mM}$ Tris- $\mathrm{HCl} \mathrm{pH}$ $7.5,90 \mathrm{mM} \mathrm{KCl}, 1.8 \mathrm{mM} \mathrm{MgCl}_{2}, 1.8 \mathrm{mM}$ EDTA, 9\% glycerol, 0.11 $\mathrm{mg} / \mathrm{mL}$ BSA, $2.25 \% \mathrm{NP}-40\left(4^{\circ} \mathrm{C}, 10 \mathrm{~min}\right)$ and loaded into the gel.

Once we confirmed that the $\mathrm{Glu}_{8}$ acidic appendages significantly impaired the DNA binding, we investigated the photocleavage of the ANP linker. Unfortunately, HPLC analysis of the irradiated solution of $\phi\left(\mathbf{E}_{\mathbf{8}} \mathbf{b r}\right)_{2}(30 \mathrm{sec} . \lambda=300-375 \mathrm{~nm})$ showed a complex mixture of products that could not be characterized (figure 3 , left), and from which it was not possible to isolate the expected photocleaved dimer. Addition of commonly used reagents to capture reactive photolysis byproducts, such as DTT or hydrazine, ${ }^{[20]}$ did not result in any significant improvement. Considering that the complex product mixture could arise from the degradation of highly reactive phenylnitroso ketone groups photoreleased at the N-terminus of the active peptide fragments, we modified the design, reversing the orientation of the ANP linker. ${ }^{[21]}$ The new $\phi\left(\mathbf{E}_{8} \# \mathbf{b r}\right)_{2}$ peptide contained a reconfigured ANP linker attached to the side chain of a Glu residue at the N-terminus of the basic region; cleavage of this inverted ANP would release the intact native peptide leaving a natural Gln residue at the N-terminus $\left(\phi(\mathbf{Q} \# \mathbf{b r})_{2}\right.$, Scheme 1).

The revamped $\phi\left(\mathbf{E}_{8} \# \mathbf{b r}\right)_{2}$ peptide was synthesized following a similar procedure to that described previously for the synthesis of $\phi\left(\mathbf{E}_{8} \mathbf{b r}\right)_{2}$. Gratifyingly, we found that photolysis of $\phi\left(\mathbf{E}_{8} \# \mathbf{b r}\right)_{2}$ was much cleaner than that of $\phi\left(\mathbf{E}_{8} \mathbf{b r}\right)_{2}$, as shown by the HPLC analysis of the reaction mixture (figure 3 , and supporting information).

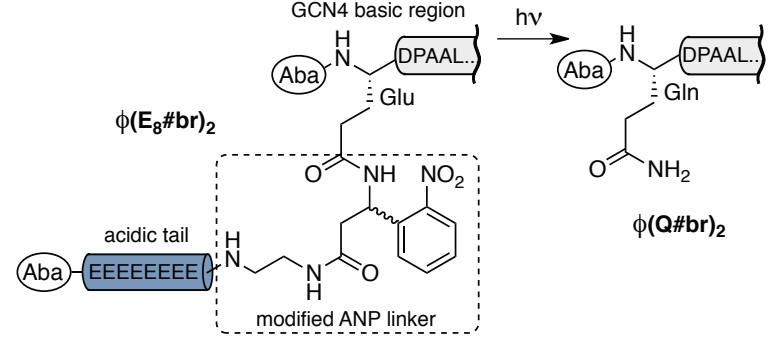

Scheme 1. Structure of the modified photolabile basic regions with the reversed ANP linker connected through a Glu side chain $\left(\phi\left(E_{8} \# \mathbf{b r}\right)_{2}\right)$, and the expected photodissociation product, $\phi(\mathbf{Q} \# \mathbf{b r})_{2}$.
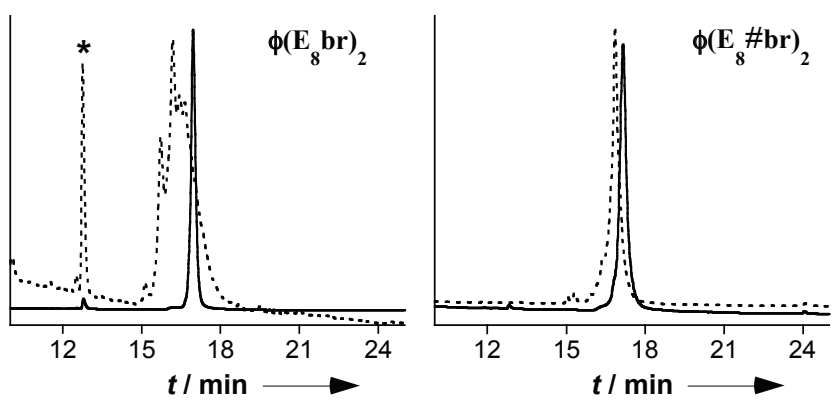

Figure 3. HPLC traces of the irradiated buffered solutions of $\phi\left(E_{8} b r\right)_{2}$ (left) and $\phi\left(E_{8} \# \mathbf{b r}\right)_{2}$ (right), showing the improved photolysis in the reversed design ( 5 to $75 \%, 0.1 \% \mathrm{TFA} \mathrm{CH} \mathrm{CN}_{3} \mathrm{CH} \mathrm{H}_{2} \mathrm{O}$ ). Solid lines represent the starting dimers, dashed lines are the chromatograms after $30 \mathrm{sec}$ irradiation. The acidic tail released upon irradiation of $\phi\left(E_{8} b r\right)_{2}$ is marked with an asterisk. The major peak in the trace at the right corresponds to the expected uncaged dimer $\phi(\mathbf{Q \# b r})_{2}$. The photoreleased acidic tail containing the reactive nitrosoketone group is not observed in this case, probably because it decomposes and the degraded products are eluted with the injection peak; traces of the dimer with one acidic tail were also observed in the MALDI spectra (supporting information). Y-axis scale in arbitrary absorbance units.

As expected, the inverted peptide $\phi\left(\mathbf{E}_{8} \# \mathbf{b r}\right)_{2}$ qualitatively reproduces the DNA-binding behavior observed with the original $\phi\left(\mathbf{E}_{\mathbf{8}} \mathbf{b r}\right)_{2}$ peptide. Thus incubation of $\phi\left(\mathbf{E}_{8} \# \mathbf{b r}\right)_{2}$ with a double stranded oligonucleotide containing the ATF/CREB target sequence did not show significant retarded bands in the PAGE experiments (figure 4, top, lanes 2-5). Irradiation of a $50 \mu \mathrm{M}$ solution of $\phi\left(\mathbf{E}_{\mathbf{8}} \# \mathbf{b r}\right)_{2}$ in $10 \mathrm{mM}$ Tris-HCl pH 6.8 buffer, for $30 \mathrm{sec}$ with a standard gel transilluminator lamp, and subsequent incubation with the same oligonucleotide, resulted in the appearance of retarded gel bands, consistent with a specific peptide-DNA complex (figure 4, top, lanes 6-9). ${ }^{[22]}$ Moreover, these bands were similar to those observed using the $\phi(\mathbf{Q} \# \mathbf{b r})_{2}$ peptide dimer, which was purposely synthesized de novo as a true uncaged control. As expected, incubation of the irradiated sample of $\phi\left(\mathbf{E}_{8} \# \mathbf{b r}\right)_{2}$ with a random DNA did not result in any new band (figure 4, top, lane 10). In addition to the experiments with the symmetrically caged $\phi\left(\mathbf{E}_{\mathbf{8}} \# \mathbf{b r}\right)_{2}$, we synthesized a single-caged $\phi(\mathbf{Q} \# \mathbf{b r})\left(\mathbf{E}_{8} \# \mathbf{b r}\right)$ peptide, in which only one of the basic regions was modified with the acidic tail. Remarkably, this peptide retained a significant DNA binding affinity, showing in the EMSA gels as a slightly slower migrating band than that of the complex with the uncaged control $\phi(\mathbf{Q} \# \mathbf{b r})_{2}$ (figure S17, supporting information).

Importantly, the photochemical activation can be carried out in the presence of the DNA. Therefore, irradiating a mixture of 
$\phi\left(\mathbf{E}_{8} \# \mathbf{b r}\right)_{2}$ and the target oligonucleotide allowed a substantial recovery of the DNA binding, as shown by EMSA (figure 4, bottom, lanes 3-5). An irradiation control experiment with a random oligonucleotide confirmed the specificity of the interaction, as in this case we did not observe the formation of new retarded bands in the gel (figure 4, bottom, lanes 8-10).

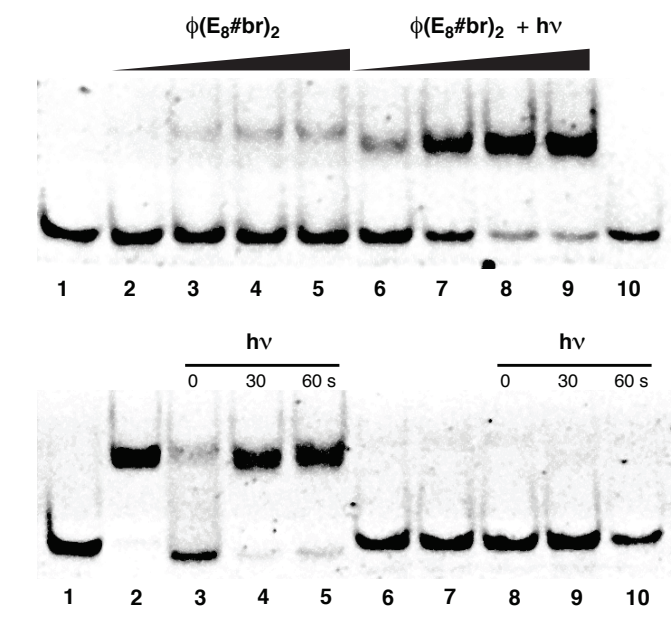

Figure 4. EMSA analysis of DNA binding by $\phi\left(\mathrm{E}_{8} \# \mathrm{br}\right)_{2}$ at $4{ }^{\circ} \mathrm{C}$. Top: Lanes 1-9: target ATF/CREB oligo (50 nM). Lanes 2-5: 125, 250, 400, $600 \mathrm{nM} \phi\left(\mathrm{E}_{8} \# \mathrm{br}\right)_{2}$, no irradiation; lanes 6-9: 125, 250, 400, $600 \mathrm{nM}$ $\phi\left(E_{8} \# \mathbf{b r}\right)_{2}$, after 30 sec. irradiation with UV light $(10 \mathrm{mM}$ Tris- $\mathrm{HCl}, \mathrm{pH}$ 6.8); lane 10: $600 \mathrm{nM} \phi\left(\mathrm{E}_{8} \# \mathrm{br}\right)_{2}$ after $30 \mathrm{sec}$. irradiation and addition of a random oligo ( $r n d D N A, 50 \mathrm{nM}$, see supporting information for full sequence). Bottom: DNA binding of $\phi\left(E_{8} \# b r\right)_{2}$; irradiation in the presence of the oligonucleotide (10 mM Tris- $\mathrm{HCl}, \mathrm{pH} 6.8)$. Lanes 1-5: target ATF/CREB oligo (50 nM). Lane 2: control peptide $\phi$ br $_{2}$ (300 $\mathrm{nM})$. Lanes 3-5: $\phi\left(\mathrm{E}_{8} \# \mathbf{b r}\right)_{2}(300 \mathrm{nM})$ at increased irradiation times; lanes 6-10: rndDNA (50 nM); lane 7: control, $\phi$ br $_{2}$ (300 nM); lanes 810: $\phi\left(E_{8} \# \mathbf{b r}\right)_{2}(300 \mathrm{nM})$ at increasing irradiation times.

It is well known that the DNA binding of bZIP dimers is coupled to their folding into $\alpha$-helical conformations. ${ }^{[23]}$ Therefore we made complementary circular dichroism studies to gain some structural insight into the DNA binding process. These experiments showed that the caged dimer $\phi\left(\mathbf{E}_{8} \# \mathbf{b r}\right)_{2}$ is essentially unstructured in the absence of DNA (figure 5, left, dashed line). Addition of the target ATF/CREB oligonucleotide induced a significant increase in the negative CD signal at $222 \mathrm{~nm}$, consistent with an increase in the $\alpha$ helical content of the peptide that could result from the high concentrations required to run the $\mathrm{CD}$ experiments $(5 \mu \mathrm{M}$ of peptide and DNA), or from non-specific interactions with the dsDNAs. ${ }^{[24]}$ More importantly, UV irradiation of this $\phi\left(\mathbf{E}_{8} \# \mathbf{b r}\right)_{2} /$ oligonucleotide mixture led to a large increase in the negative ellipticity, in the range of what has been observed when this type of dimers fold upon interacting with their target DNA sites (figure 5, left). ${ }^{[23]}$

In order to further confirm these results and rule out any distortions associated with the gel shift experiments, we performed fluorescence anisotropy titrations that provided a more quantitative characterization of the DNA recognition process. ${ }^{[25]}$ Incubation of a fluorescein-labeled ATF/CREB oligonucleotide with increasing amounts of $\phi(\mathbf{Q} \# \mathbf{b r})_{2}$ resulted in a progressive increase of the anisotropy, which was consistent with the formation of a DNA complex with higher molecular weight and reduced mobility. ${ }^{[26]}$ Fitting of the resulting isotherm to a $1: 1$ binding model, ${ }^{[27]}$ allowed to calculate its dissociation constant $\left(K_{D} \approx 38 \mathrm{nM}\right)$. As expected, the caged derivative $\phi\left(\mathbf{E}_{\mathbf{8}} \# \mathbf{b r}\right)_{2}$ showed drastically weaker binding than the control peptide under the same conditions $\left(K_{D} \approx 1 \mu \mathrm{M}\right.$, figure 5, right). Moreover, the uncaging process could be monitored by fluorescence anisotropy. Thus, irradiation of the caged $\phi\left(\mathbf{E}_{\mathbf{8}} \# \mathbf{b r}\right)_{2}$ peptide in the presence of the fluorescently-labeled ATF/CREB oligonucleotide resulted in an anisotropy value similar to that obtained when the target oligonucleotide is incubated with the $\phi(\mathbf{Q} \# \mathbf{b r})_{2}$ control peptide (bar graph, figure 5, right).

In conclusion, we have demonstrated that the attachment of a negatively charged tether to an Arg/Lys-rich bZIP based peptide can effectively hamper its DNA recognition ability. Moreover, connecting this appendage through a photocleavable ANP linker allows to restoring the DNA binding upon simple UV irradiation. The negatively charged patch might disturb the binding both, by interfering with electrostatic pairing, or by generating repulsive contacts with the DNA. Typical photocaging or switching strategies are based on the modification of specific key residues, and usually require linear synthetic processes as well as detailed structural knowledge of the interaction. Our "electrostatic turn-off" strategy, by relying on simple tethering of highly charged appendages to the natural recognition elements, should provide a facile, versatile and general route to temporarily control specific biological interactions involving highly charged partners such as nucleic acids. Furthermore, this method seems particularly appropriate for modulating interactions involving multivalent contacts that might tolerate a single caging group.

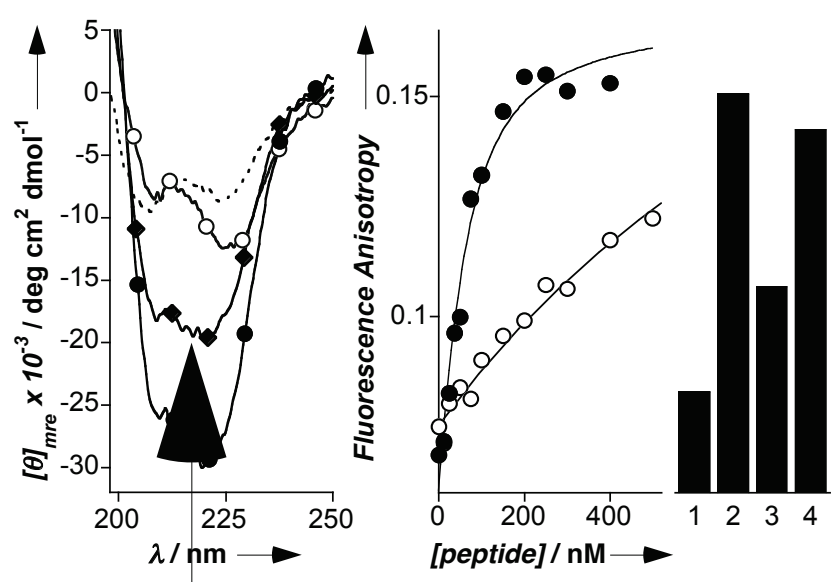

Figure 5. Left: CD spectra of $5 \mu \mathrm{M} \phi\left(\mathrm{E}_{8} \# \mathrm{br}\right)_{2}$ in $10 \mathrm{mM}$ Tris- $\mathrm{HCl}$, pH 6.8 , at $4{ }^{\circ} \mathrm{C}$ (dashed line). Solid lines: $\phi\left(\mathrm{E}_{8} \# \mathbf{b r}\right)_{2}$ after $30 \mathrm{sec}$ irradiation (O); $\phi\left(E_{8} \# \mathbf{b r}\right)_{2}$ in the presence of $5 \mu \mathrm{M}$ of the target oligo ATF/CREB before $(\diamond)$, and after $30 \mathrm{sec}$. irradiation $(\bullet)$. Center: Fluorescence anisotropy titrations at $518 \mathrm{~nm}$ of a fluorescein-labeled ATF/CREB $(50 \mathrm{nM})$ with $\phi\left(\mathrm{E}_{8} \# \mathbf{m b r}\right)_{2}(\mathrm{O})$, with the $\phi(\mathbf{Q} \# \mathbf{b r})_{2}$ control $(\bullet)$, and best fit to a simple 1:1 binding model $(10 \mathrm{mM}$ Tris- $\mathrm{HCl}$ buffer, 10 $\mathrm{mM} \mathrm{NaCl}, \mathrm{pH} 6.8$ at $10^{\circ} \mathrm{C}$ ). Right: fluorescence anisotropy values:

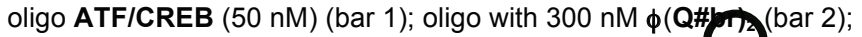
same oligo with $300 \mathrm{nM} \phi\left(\mathrm{E}_{8} \# \mathbf{b r}\right)_{2}$ (bar 3), and with $300 \mathrm{nM} \phi\left(\mathrm{E}_{8} \# \mathbf{b r}\right)_{2}$ after $60 \mathrm{sec}$ irradiation (bar 4). Same scale as the titrations.

Received: ((will be filled in by the editorial staff))

Published online on ((will be filled in by the editorial staff))

Keywords: peptides - DNA recognition - protein design . photochemistry $\cdot$ amino acids 
[1] D. S. Latchman, Eukaryotic Transcription Factors, Elsevier, London, 2004.

[2] J. E. Darnell Jr., Nat. Rev. Cancer 2002, 2, 740-749.

[3] C. W. Garvie, C. Wolberger, Mol. Cell 2001, 8, 937-946; Y. Choo, A. Klug, Curr. Opin. Struct. Biol. 1997, 7, 117-125; N. M. Luscombe, R. A. Laskowski, J. M. Thornton, Nucleic Acids Res. 2001, 29, 2860-2874; Y. Mandel-Gutfreund, O. Schueler, H. Margalit, J. Mol Biol. 1995, 253, 370-382.

[4] T. Härd, T. Lundbäck, Biophys. Chem. 1996, 62, 121-139; J. Norberg, Arch. Biochem. Biophys. 2003, 410, 48-68. (c) A. G. Cherstvy, J. Phys. Chem. B 2009, 113, 4242; V. R. Ramirez-Carrozzi, T. K. Kerppola, J. Mol. Biol. 2001, 305, 411-427; C. O. Pabo, R. T. Sauer, Annu. Rev. Biochem. 1992, 61, 1053-1095.

[5] A. Nomura, A. Okamoto, Chem. Commun. 2009, 1906-1908; F. Zhang, K. A. Timm, K. M. Arndt, G. A. Woolley, Angew. Chem. Int. Ed. 2010, 49, 3943-3946; S.-A. Morgan, M. S. Al-Abdul-Wahid, G. A. Woolley, J. Mol. Biol. 2010, 399, 94-112.

[6] S.-A. Morgan, G. A. Woolley, Photochem. Photobiol. Sci. 2010, 9, 1320-1326.

[7] R. Wieboldt, K. R. Gee, L. Niu, D. Ramesh, B. K. Carpenter, G. P. Hess, Proc. Natl. Acad. Sci. USA 1994, 91, 8752-8756; A. Nguyen, D. M. Rothman, J. Stehn, B. Imperiali, M. B. Yaffe, Nature Biotech. 2004, 22, 993-1000; M. E. Vázquez, M. Nitz, J. Stehn, M. B. Yaffe, B. Imperiali, J. Am. Chem. Soc. 2003, 125, 10150-10151.

[8] H. Yu, J. Li, D. Wu, Z. Qiu, Y. Zhang, Chem. Soc. Rev. 2010, 39, 464-473; Y. Ohmuro-Matsuyama, Y. Tatsu, Angew. Chem. Int. Ed. 2008, 47, 7527-7529; A. Gautier, D. P. Nguyen, H. Lusic, W. An, A. Deiters, J. W. Chin, J. Am. Chem. Soc. 2010, 132, 4086-4088; D. Humphrey, Z. Rajfur, M. E. Vázquez, D. Scheswohl, M. D. Schaller, K. Jacobson, B. Imperiali, J. Biol. Chem. 2005, 280, 22091-22101.

[9] A. M. Caamaño, M. E. Vázquez, J. Martínez-Costas, L. Castedo, J. L. Mascareñas, Angew. Chem. Int. Ed. 2000, 39, 3104-3107; L. Guerrero, O. S. Smart, G. A. Woolley, R. K. Allemann, J. Am. Chem. Soc. 2005, 127, 15624-15629.

[10] J. Andersson, S. Li, P. Lincoln, J. Andréasson, J. Am. Chem. Soc. 2008, 130, 11836-11837; M. L. Di Pietro, F. Puntoriero, F. Tuyéras, P. Ochsenbein, P. P. Lainé, S. Campagna, Chem. Commun. 2010, 46, 5169-5171.

[11] M. I. Sánchez, O. Vázquez, M. E. Vázquez, J. L. Mascareñas, Chem. Commun. 2011, 47, 11107-11109; O. Vázquez, M. I. Sánchez, J. Martínez-Costas, M. E. Vázquez, J. L. Mascareñas, Org. Lett. 2010, 12, 216-219; M. I. Sánchez, J. Martínez-Costas, F. González, M. A. Bermúdez, M. E. Vázquez, J.L. Mascareñas, ACS Chem. Biol. 2012, DOI: $10.1021 / \mathrm{cb} 300100 \mathrm{r}$

[12] E. S. Olson, T. A. Aguilera, T. Jiang, L. G. Ellies, Q. T. Nguyen, E. H. Wong, L. A. Gross, R. Y. Tsien, Integrative Biol. 2009, 1, 382-292; T. Jiang, E. S. Olson, Q. T. Nguyen, M. Roy, P. A. Jennings and R. Y. Tsien, Proc. Natl. Acad. Sci. U. S. A., 2004, 101, 17867-17872.

[13] T. E. Ellenberger, C. Brandl, K. Struhl, S. C. Harrison, Cell 1992, 71, 1223-1237; P. König, T. J. Richmond, J. Mol. Biol. 1993, 233, $139-154$.

[14] E. Pazos, J. Mosquera, M. E. Vázquez, J. L. Mascareñas, ChemBioChem 2011, 12, 1958-1973; M. E. Vázquez, A. M. Caamaño,
J. L. Mascareñas, Chem. Soc. Rev. 2003, 32, 338-349; M. E. Vázquez, A. M. Caamaño, J. Martínez-Costas, L. Castedo, J. L. Mascareñas, Angew. Chem. Int. Ed. 2001, 40, 4723-4725; S.-I. Sato, M. Hagihara, K. Sugimoto, T. Morii, Chem. Eur. J. 2002, 8, 5066-5071.

[15] R. V. Talanian, C. J. McKnight, R. Rutkowski, P. S. Kim, Biochemistry 1992, 31, 6871-6875. For other DNA-binding bZIPbased peptides see: J. Blanco, M. E. Vázquez J. Martínez-Costas, L. Castedo, J. L. Mascareñas Chem Biol. 2003 10, 713-722; J. B. Blanco, O. Vázquez, J. Martínez-Costas, L. Castedo, J. L. Mascareñas, Chem. Eur. J. 2005, 11, 4171-4178; O. Vazquez, M. E. Vazquez, J. B. Blanco-Canosa, L. Castedo, J. L. Mascareñas, Angew. Chem. Int. Ed. 2007, 46, 6886-6890.

[16] C. Grunwald, K. Schulze, A. Reichel, V. U. Weiss, D. Blaas, J. Piehler, K.-H. Wiesmüller, R. Tampé, Proc. Natl. Acad. Sci. USA 2010, 107, 6146-6151; M. Nitz, K. J. Franz, R. L. Maglathlin, B. Imperiali, ChemBioChem 2003, 4, 272-276.

[17] See the supporting information. For this type of disulfide formation, see: G. T. Hermanson, Bioconjugate Techniques, Academic Press/Elsevier, London, 2008; S. Arpicco, F. Dosio, P. Brusa, P. Crosasso, L. Cattel, Bioconjugate Chem. 1997, 8, 327-337.

[18] W. Hendrickson, BioTechniques 1985, 3, 346-354; A. Revzin, BioTechniques 1989, 7, 346-354; D. Lane, P. Prentki, M. Chanler, Microbiol. Rev. 1992, 56, 509-529; L. M. Hellman, M. G. Fried, Nature Protocols 2007, 2, 1849-1861.

[19] This figure is a composite of two independent experiments of $\mathbf{b r}_{2}$ and $\phi \mathbf{b r}_{2}$ with $\phi\left(\mathbf{E}_{4} \mathbf{B r}\right)_{2}$, and $\phi\left(\mathbf{E}_{8} \mathbf{B r}\right)_{2}$.

[20] O. Ito, M. Matsuda, Bull. Chem. Soc. Jpn. 1978, 51, 427-430; O. Mozziconacci, V. Sharov, T. D. Williams, B. A. Kerwin, C. Schöneich, J. Phys. Chem. B 2008, 112, 9250-9257.

[21] C. J. Bosques, B. Imperiali, J. Am. Chem. Soc. 2003, 125, 7530-7531.

[22] The shift of this band is matches that of a specifically synthetized dimeric control peptide $\phi(\mathbf{Q} \# \mathbf{b r})_{2}$ (see supporting information).

[23] R. V. Talanian, C. J. McKnight, P. S. Kim, Science 1990, 249, 769-771; Y. Aizawa, Y. Sugiura, T. Morii, Biochemistry, 1999, 38, 1626-1632; G. Holzwarth, P. Doty, J. Am. Chem. Soc. 1965, 87, 218-228.

[24] Related structuring effects have been observed with positively charged peptides as a result of low affinity and non-specific interactions with DNA: A. Zlotnick, S. L. Brenner, J. Mol. Biol. 1988, 209, 447-457; K. Niikura, H. Matsuno, Y. Okahata, Chem. Eur. J. 1999, 5, 1609-1616; N. P. Johnson, J. Lindstrom, W. A. Baase, P. H. von Hippel, Proc Natl Acad Sci USA 1994, 91, 4840-4844.

[25] B. J. Anderson, C. Larkin, K. Guja, J. F. Schildbach, Methods Enzymol. 2008, 450, 253-272; G. H. Bird, A. R. Lajmi, J. A. Shin, Biopolymers 2002, 65, 10-20.

[26] V. J. LiCata, A. J. Wowor, Methods Cell Biol. 2008, 84, 243-262; B. J. Anderson, C. Larkin, K. Guja, J. F. Schildbach, Methods Enzymol. 2008, 450, 253-272.

[27] J. R. Lundblad, M. Laurance, R. H. Goodman, Mol. Endocrinol 1996, 10, 607-612. Experimental data were fitted with the DynaFit 3 software. P. Kuzmic, Anal. Biochem. 1996, 237, 260-273. 


\section{(Electrostatic caging)}

Adrián Jiménez-Balsa, Elena Pazos, Borja Martínez-Albardonedo, José L. Mascareñas* and M. Eugenio Vázquez* Page - Page

Temporary electrostatic impairing of DNA recognition. Light driven DNAbinding of peptide dimers derived from a bZIP transcription factor
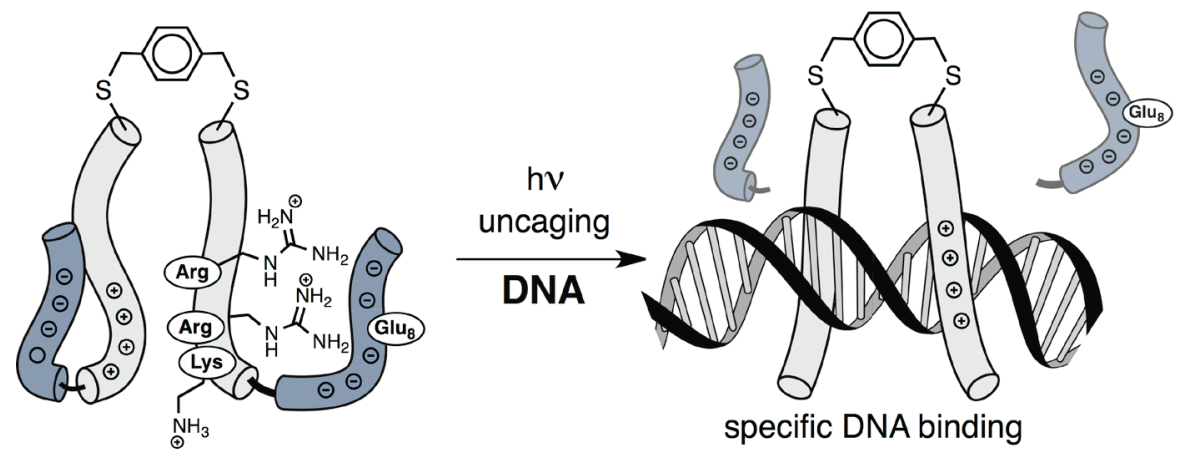

Appending negatively charged Glu $\mathrm{u}_{8}$ tails to a peptide dimer derived from the GCN4 transcription factor leads to an effective suppression of its DNA binding. The specific DNA recognition can be restored by irradiation with UV light, owing to the use of a photolabile linker between the acidic tail and the DNA binding peptide. 